\title{
Synergistic interaction of education, science, and industry
}

\author{
Vladimir Klimuk $^{1} \cdot$ Anna Tarasova $^{2}\left[{ }^{-} \cdot\right.$ Kuznetsova Yulia $^{3} \cdot$ Dzhabrailova Laura $^{4}$
}

Received: 18 July 2019 / Accepted: 21 April 2020 / Published online: 29 April 2020

(c) The Author(s) 2020

\begin{abstract}
Economic and social development of a country rely on advanced science and technology, skilled, educated workforce, extensive growth of innovation and population density. The process of innovation creation can be long and winding and should take into account the needs of technological development and definitely bring benefits to business. The concept of a science park has not been new. The United States of America were pioneers who in early 1950s suggested a brand new model for bridging the gap between academia and industry. Nowadays developed countries employ that model, though its objectives, funds, inputs and outcomes may vary. This paper will focus of the issue of real interaction of institutions of education, science and industry and will raise a number of controversial issues in the correction of the vector for socio-economic modernization. The authors analyzed a set of legislation acts on regulating the cooperation of academia and business. The paper gives a graphical model of reciprocity of institutions of education, science, and industry taking into account the interests of public authorities, and offers a set of additional indicators of evaluation of the efficiency of functioning of an innovation structure in the country (region).
\end{abstract}

Keywords Innovation infrastructure - Interaction of education, science, and industry · Synergistic effect · Indicators of evaluation of interaction efficiency

\section{Introduction}

The dynamic of quality of the demands concerning the expected goods, and the model of digitalization of the economy form a motivating range of actions for securing the competitiveness of institutions, regions and the country

Anna Tarasova

tarasovaan@volgatech.net

Vladimir Klimuk

klimuk-vv@yandex.ru

Kuznetsova Yulia

acanaria2005@mail.ru

Dzhabrailova Laura

laura-grozny@mail.ru

1 Baranovichi State University, 21 Voikov Str., 225404 Baranovichi, Republic of Belarus

2 Volga State University of Technology, 3 Lenin Square, 424000 Yoshkar-Ola, Russian Federation

3 T.F. Gorbachev Kuzbass, State Technical University, 28 Vesennya Str., 650000 Kemerovo, Russian Federation

4 Chechen State Pedagogical University, 33 Kiev Str., Chechen Republic, 364031 Grozny, Russian Federation
(Carayannis and Sagi 2001). The society needs new products, and services which reduce the labor intensity of the realization process and quantity of laborresources increase the functionality level decrease the dimensional parameters of the development, thereby minimizing costs on its creation (execution) (Mansour and Kanso 2018). Generating new ideas, their approbation and introduction into practice of functioning institutions are the most important tasks of the society (Yasheva 2008; Steruska et al. 2019).

Innovations are a dominant of the socio-economic growth of the country, that create a platform for the acceleration of technical and technological modernization, socio-ecologiceconomic security of society (Klimuk and Semashko 2018). The goal vector in the system development of a country is a synergistic mechanism of interaction of educational, scientific and business components that gives an opportunity to create a new product with the improved characteristics, creating environment for developing innovation initiatives of designers, the opportunities of commercialization of the received results of intellectual property (Vásquez-Urriago et al. 2016).

All these make a basis for sustainable development, implementation of innovation solutions in the structural 
elements of the socio-economic system. Educational environment being a platform for training future specialists must immediately adapt to the dynamics of trends in various professional areas. A university should be a practice-driven and innovativeelement securing the realization of practical skills of the trainees in the real conditions (Bakouros et al. 2002). Moreover, special meaning should be given to a sustainablefacilities and resources that are a crucial instrument of the concepts and processes under review (Díez-Vial and Montoro-Sánchez 2016).

The objective of the paper is to offer a mechanism for the cooperation of academia, industry, and government based on the proposed models, and methods for assessing the effectiveness of cooperation ties.

The data was taken from official statistical publications of the Republic of Belarus; world statistical agencies-World Statistics, that contributed to the comparative analysis of the state of the country; questionnaires of experts from Belarus, Russia, Poland, Latvia, China for 2016-2018 on mechanisms of academia and industrial cooperation, and their visions of the most effective models for the synergy of science and business; the regulatory legal portal. The data were used to develop optimal means of interaction between sectors and potential economic benefits. The results are visually described in Figs. 1 and 2 and in Tables 1 and 2.

The authors used the following research methods: (1) the program-target method, reflecting a phased algorithm for implementing and adopting the selected action strategies based on a set of specific activities, performers, and terms, indicating a specific economic and (or) social effect (Figs. 1 and 2) index method, which allows to conduct a qualitative analysis of the status and dynamics of the development of the system of scientific and innovative infrastructure by determining the sensible spots of activity on the basis of a system of quantitative indicators-(Table 2) method of institutional infrastructure, allowing to assess the efficiency of legal acts on the issue-(Table 1).

\section{Conceptualizing interaction of institutions of education, science, and industry}

Nowadays institutions of education adapt to a new model of their development-interaction of educational, scientific and real sectors of economy-with a consistent logic passing through each of the of intellectual activity: training, practice, scientific research, innovation development, realization to the market on commercial basis (Benny et al. 2019). Firstly, there is a formation of economic knowledge; secondly, the results of intellectual activity reflect in the practice of work of industrial enterprises, services organizations, representatives of small and medium-sized enterprises, governing bodies with the focus on innovation (Kuznetsov and Engovatova 2016) (Fig. 1).

Figure 1 shows the process of interconnection and cooperation of fundamental (basic) components in the concept of a Quadruple Innovation Helix of economic development (Carayannis and Grigoroudis 2016): "educational component", "scientific component", "business component", and "institutional component". The tools shown in Fig. 1 do not encompass all possible policy instruments to promote knowledge transfer and are subject to change. The reasoning of the process of interaction between these sectors is the following:

1. The primarily objective of the educational sector is to prepare highly qualified specialists who meet modern market requirements with the use of new teaching methods, practical orientation of the educational programs, the use of top notch teaching aids, and the development of material and technical infrastructure.

2. The scientific sector strives to create a high-tech product (work or service). Moreover, the product should be demanded. The principle of the modern market: "to produce what we need, but not what we are able to". Scientific organizations, educational institutions carry out research compatible with the country's priority areas in a global sense; they write and submit project applications for research work.

3. The business sector acts as a catalyst for the process of financing and promoting development in the real sector of the economy, providing a transfer of innovation as the main lever for increasing the competitiveness of the socio-economic system.

4. The institutional component is a society and government bodies that act as customers, consumers of innovative products, results of scientific activity, lobby the interests of certain segments of the population, citizens of the country in order to improve life spheres, forming flexible instruments of legal regulation of scientific and innovative transformation.

An innovation infrastructure forms with the purpose of innovation activity of the country institutions in the course of creating new goods and their implementation to the real sector of economy (Neborsky 2017; Kallas 2011). In the Republic of Belarus the innovation infrastructure are presented by the following functional elements:

- Science park;

- Center of technology transfer;

- Venture organization (Fig. 2).

"One of the main levers of commercialization of scientific-technical achievements and development of small and 


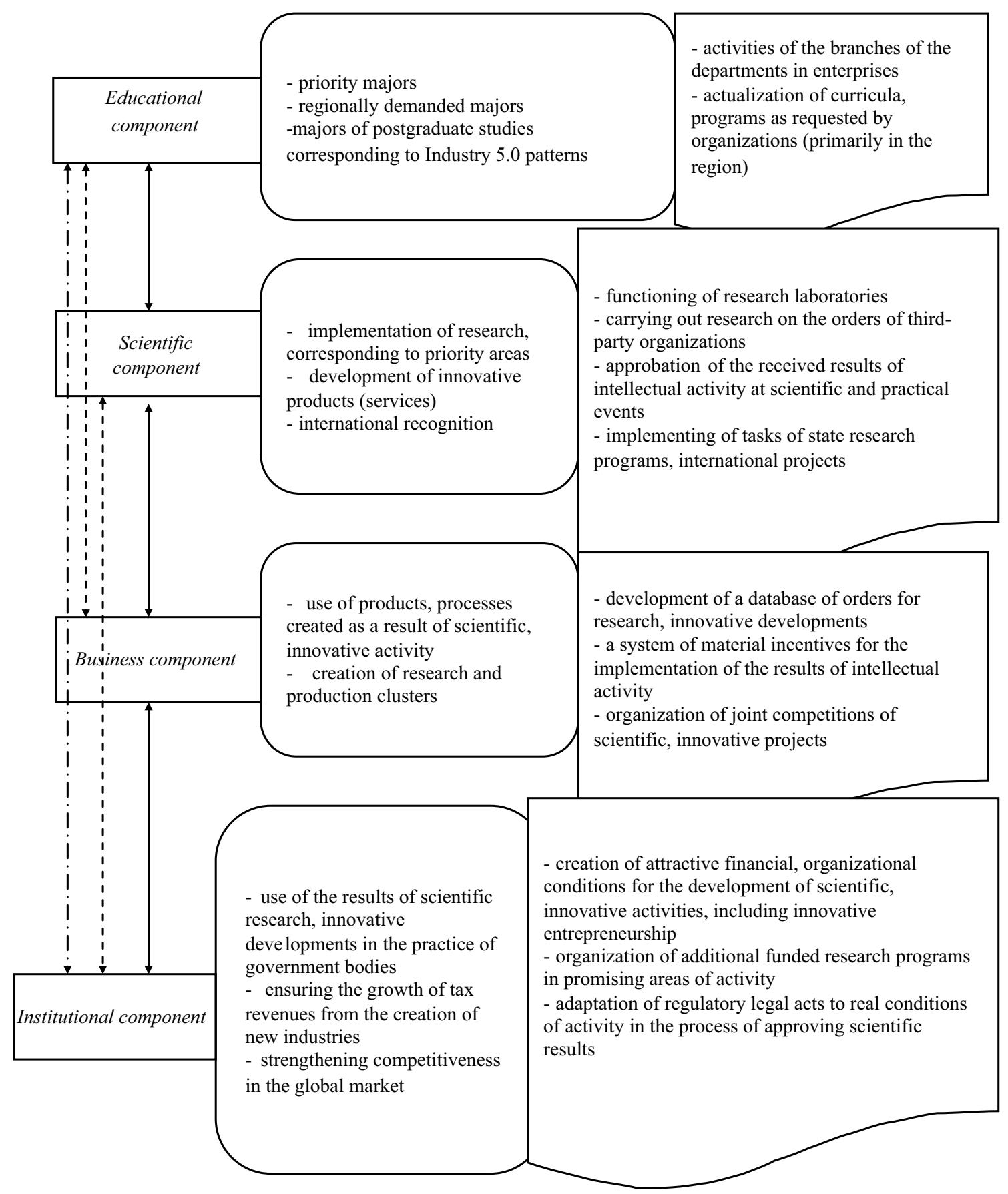

Fig. 1 The model of interaction of institutions of education, science, and industry Source: own results

middle-sized innovation entrepreneurship is the innovation infrastructure" - said the Chairman of the State Committee on science and technologies of the Republic of Belarus Alexander Shumilin (Citation at: http://www.belta.by/inter view/view/shumilin-o-razvitii-tehnoparkov-v-belarusi-innov atsionnyh-proektah-i-vysokotehnologichnyh-tovarah-5998).

The given tendency of growth of the subjects of innovation infrastructure in the country will intend to develop innovation entrepreneurship, to design and manufacture the products of the Industry 4.0 technology patterns by enterprises (Frank et al. 2019).

The institutional platform of the Republic of Belarus on creating the environment for efficient development of innovation entrepreneurship is being improved (Table 1).

However, we are still witnessing a number of problems in the development of innovation infrastructure, such as: 


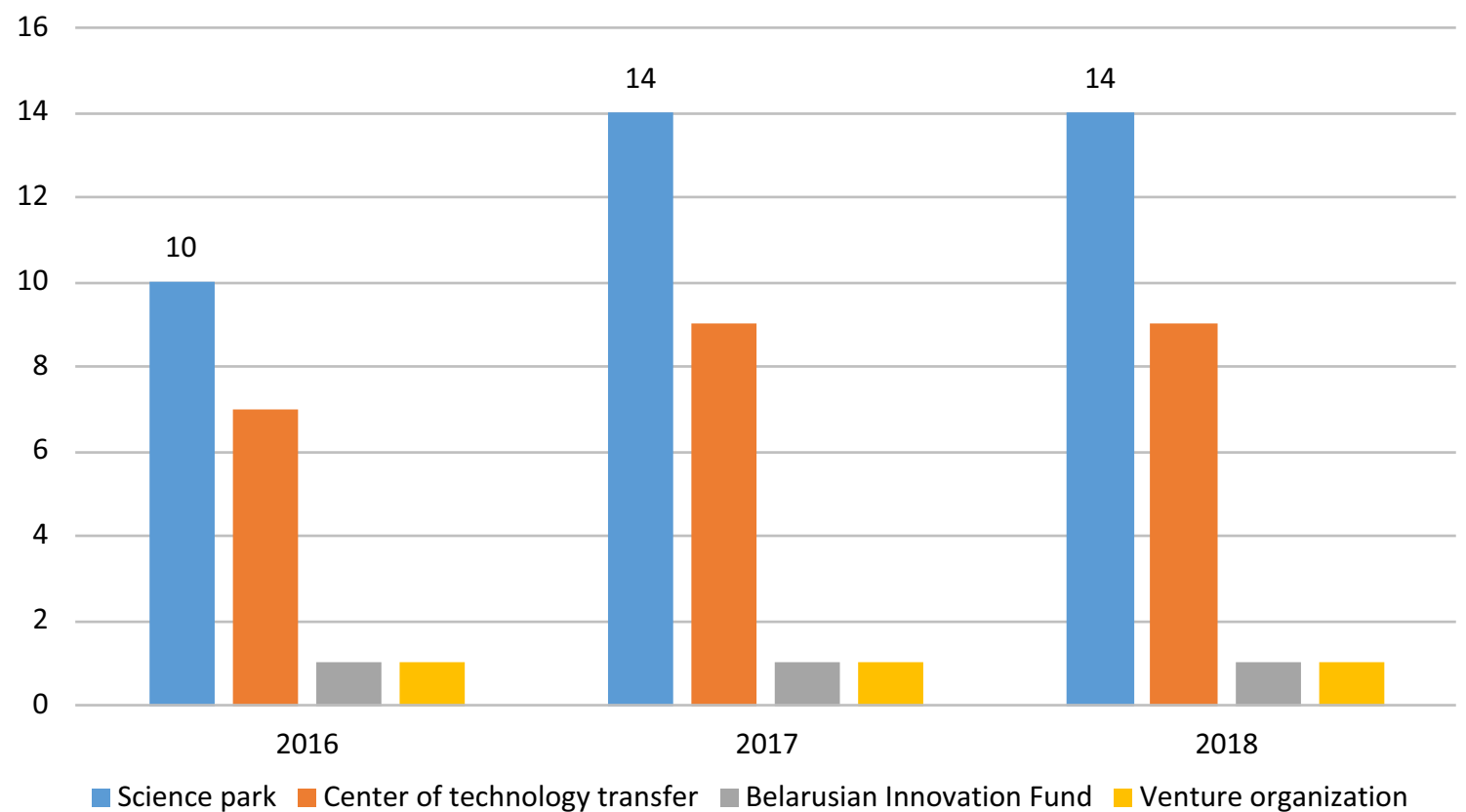

Fig. 2 Dynamics of subjects of innovation infrastructure of the Republic of Belarus, quantity Source: own results

Table 1 Legislative documents regulating efficient innovation activity in the Republic of Belarus Source: own results

Name of the document

1. Decree of the President of the Republic of Belarus No. 1 of January 3, 2007, on the Approval of the Regulation on the Procedure for Creating Innovative Infrastructure Subjects (as amended by the Decree of the President of the Republic of Belarus on 12.03.2018 No. 1)

2. Decree of the President of the Republic of Belarus No. 31 of January 31, 2017, "On the State Program of Innovative Development of the Republic of Belarus for 2016-2020"

3. Decree of the President of the Republic of Belarus No. 357 of August 8, 2012 "On the Procedure for the Formation and Use of Innovative Funds"

4. Resolution of the Council of Ministers of the Republic of Belarus of June 23, 2012 No. 574 (as amended by the Resolution of the Council of Ministers of the Republic of Belarus of November 10, 2017 No. 839) "List of high-tech goods of the Republic of Belarus"

\section{Description}

The document first categorized terminological apparatus

It formed the algorithm of actions for registration of legal entities as subjects of the innovation infrastructure

It determined the procedure for acquiring the status of a tech park resident by legal entities and individual entrepreneurs

It is aimed at achieving the priorities of the socio-economic development of the Republic of Belarus for 2016-2020 in the field of effective investments and accelerated development of innovative sectors of the economy and is the main document ensuring the implementation of the most important areas of state innovation policy

The document defines the conditions for the allocation of funds for the implementation of innovative projects

It presents the order of formation, and use of innovative funds

It highlights the criteria for financing innovative projects: the level of value added; export orientation; novelty products

The document lists high-tech goods of the Republic of Belarus in accordance with the single Commodity Nomenclature of Foreign Economic Activity of the Eurasian Economic Union
Table 2 The results of calculation of the indicators of the vector of dynamics of the innovation infrastructure in the Republic of Belarus for 2016-2018 Source: own results

\begin{tabular}{llll}
\hline Indicator & 2016 year & 2017 year & 2018 year \\
\hline 1. Rate of change of quantity of subjects of innovation infrastructure & 1.11 & 1.20 & 1.35 \\
2. Rate of change of quantity of residents of innovation infrastructure & 1.10 & 1.17 & 1.22 \\
$\begin{array}{l}\text { 3. Rate of change of the volume of the produced products by the } \\
\text { subjects of innovation infrastructure }\end{array}$ & 1.03 & 1.05 & 1.10 \\
\hline
\end{tabular}


- Organizational (lack of free space for residents-subjects of innovation structures, high-cost equipment);

- Financial (costs for the functioning of tech parks, centers for technology transfer);

- Labor (lack of researchers, developers, scientific potential).

\section{What makes interaction successful?}

The main role in the realization of the concept of innovation entrepreneurship development in the country is assigned to institutions of education, scientific organizations that are science-focused, with good facilities and resources and able to introduce and implement innovations (Şimşek and Yıldırım 2016; Guadix et al. 2016). There are centers of technology transfer, science parks at universities in the Republic of Belarus proving effective interaction between spheres of education, science and business.

Educational establishment "Baranovichi State University" started this year a practice-oriented project "Project management", giving to pupils an opportunity to plan and further implement their own and team projects supervised by the university teachers, thus defining for themselves the priority majors for getting education at a university.

The University has a "Business school", "Academy of a young scientist"- schoolchildren have a chance to be prepared for a university entrance according to the chosen major, and to participate in scientific events.

At BarSU there is a preschool educational center "University for children" for 3-6 year old children for giving them an understanding of studying at a university. It helps parents to develop a concept of relevance of a university education and its quality.

Another project "Synergy" that BarSU offers aims at planning joint scientific-research project by schoolchildrenand undergraduate students supervised by the experienced teachers that once again confirms the target setting for the conscious choice of students in the popular major.

To evaluate the efficiency of functioning of the innovation infrastructure in the country (Patthirasinsiri and Wiboonrat 2017) the authors proposed a system of indicators based on calculation of the rate of change:

1. Rate of change of quantity of subjects of innovation infrastructure $(\mathrm{C})$.

2. Rate of change of quantity of residents of innovation infrastructure $(\mathrm{R})$.

3. Rate of change of the volume of the produced products by the subjects of innovation infrastructure $(\mathrm{P})$.

Rates of changes are calculated according to the indicators in the previous period. Thus, the vector of the dynamics of the innovation infrastructure can be defined on the basis of comparison of the indicators obtained in the process of calculation:

$\mathrm{C}, \mathrm{R}, \mathrm{P}>1$-progressive;

$\mathrm{C}, \mathrm{R}, \mathrm{P}=1$ - stable;

$\mathrm{C}, \mathrm{R}, \mathrm{P}<1$-regressive.

The results of calculation of the indicators of the vector of dynamics of the innovation infrastructure in the Republic of Belarus for 2016-2018 are given in Table 2.

\section{Conclusions}

The performed calculations indicate an increase in the scientific and innovative activity of organizations of the Republic of Belarus, which is evidenced by the positive dynamics of the values of all indicators from the developed system of indicators. These indicators include but not limited by the share of innovatively active organizations-subjects of innovation infrastructure, their residents and, accordingly, innovative products created on this platform, using the given resources. The increase in the number of subjects of innovation infrastructure is explicitly explained by the understanding of the target for the growth of the competitiveness of the national economy, stability and the possible use of the existing potential of the socio-economic system-through the creation of innovative products (works or services), the introduction of high-tech goods. That will be one of the mechanisms for rating growth of the national socio-economic system in the global context (Statistical Yearbook of the Republic of Belarus 2018; The most digital countries in the world 2017).

The authors suggest carrying out the intensification of scientific research, the creation of innovative products necessary for the market, which are in demand and perspective, based on a number of the tools (Guimón and Paunov 2019):

- A set of incentive measures, along with opening calls for research projects, innovative projects comprising a diverse mix of instruments counting budgetary funding, support for a group of sponsors, industry departments, local authorities, internal (local) grants;

- Forming a powerful, modern material and technical infrastructure for scientific research, developing innovative projects corresponding to Industry 5.0 technology patterns (Skobelev and Borovik 2017);

- Holding training events (seminars, trainings, master classes) on generating ideas, preparing innovative projects, preparing research projects.

The effective implementation of the objective of increasing and maximizing the use of the country's scientific 
and innovative potential-is based on the implementation of the concept of a Quadruple Innovation Helix of interaction between education, science, industry, society and government.

Baranovichi State University in the Republic of Belarus has been given as an example of synergetic interaction of academia and industry.

The Republic of Belarus is a country with a number of qualified researchers, good scientific publications and patents, which shows longing and eager society for science parks.

Positive dynamics of the given indicators characterizes the productive work in the course of innovation infrastructure development in the country, creating favorable environment for improving the vector of dynamics of innovation entrepreneurship, growth of innovation and competitive products.

The proposed graphical model of interaction of institutions of education, science, and business takes into accounts the interests and terms of the system of public authoritiesand presents a logic mechanism of cooperation based on mutual benefit for each of the functional components of synergistic chain. The presented system of additional indicators allows to conduct operational monitoring of the state and development of innovation infrastructure in the region and the country to further make decisions on which adaptive mechanisms to implement in order to strengthenthe given state.

Open Access Dieser Artikel wird unter der Creative Commons Namensnennung 4.0 International Lizenz veröffentlicht, welche die Nutzung, Vervielfältigung, Bearbeitung, Verbreitung und Wiedergabe in jeglichem Medium und Format erlaubt, sofern Sie den/die ursprünglichen Autor(en) und die Quelle ordnungsgemäß nennen, einen Link zur Creative Commons Lizenz beifügen und angeben, ob Änderungen vorgenommen wurden. Die in diesem Artikel enthaltenen Bilder und sonstiges Drittmaterial unterliegen ebenfalls der genannten Creative Commons Lizenz, sofern sich aus der Abbildungslegende nichts anderes ergibt. Sofern das betreffende Material nicht unter der genannten Creative Commons Lizenz steht und die betreffende Handlung nicht nach gesetzlichen Vorschriften erlaubt ist, ist für die oben aufgeführten Weiterverwendungen des Materials die Einwilligung des jeweiligen Rechteinhabers einzuholen. Weitere Details zur Lizenz entnehmen Sie bitte der Lizenzinformation auf http://creativecommons .org/licenses/by/4.0/deed.de.

\section{References}

Bakouros YL, Mardas DC, Varsakelis NC (2002) Science park, a high tech fantasy?: an analysis of the science parks of Greece. Technovation 22(2):123-128. https://doi.org/10.1016/S0166 -4972(00)00087-0

Benny Ng WK, Appel-Meulenbroek R, Cloodt M, Arentze T (2019) Towards a segmentation of science parks: a typology study on science parks in Europe. Res Policy 48(3):719-732. https://doi. org/10.1016/j.respol.2018.11.004
Carayannis E, Grigoroudis E (2016) Quadruple innovation helix and smart specialization: knowledge production and national competitiveness. Foresight STI Gov 10(1):31-42. https://doi.org/10.17323 /1995-459x.2016.1.31.42

Carayannis E, Sagi J (2001) New vs old economy: insights on competitiveness in the global IT industry. Technovation. 21(8):501-514

Díez-Vial I, Montoro-Sánchez A (2016) How knowledge links with universities may foster innovation: the case of a science park. Technovation 50-51:41-52. https://doi.org/10.1016/j.technovati on.2015.09.001

Frank A, Dalenogare L, Ayala N (2019) Industry 4.0 technologies: implementation patterns in manufacturing companies. Int J Prod Econ 210:15-26. https://doi.org/10.1016/j.ijpe.2019.01.004

Guadix J, Carrillo-Castrillo J, Onieva L, Navascués J (2016) Success variables in science and technology parks. J Bus Res 69(11):4870 4875. https://doi.org/10.1016/j.jbusres.2016.04.045

Guimón J, Paunov C (2019) Science-industry knowledge exchange: a mapping of policy instruments and their interactions. OECD science, technology and industry policy papers. 66. OECD Publishing, Paris. https://doi.org/10.1787/66a3bd38-en

Kallas MS (2011) The interaction of science, education and business as the basis for the formation of the innovation environment in Russia. Vestnik Tomsk State Univ Econ Law 4(16):186-191

Klimuk VV, Semashko MY (2018) Innovatization of industrial business in the direction of integration with education and science/Economic trends. http://ej.barsu.by/download/1//3_7.pdf. Accessed 28 Feb 2019

Kuznetsov EB, Engovatova AA (2016) "Universities 4.0": points of growth of the knowledge economy in Russia. Innovations 5(211):3-9

Mansour AMH, Kanso L (2018) Science park implementation-a proposal for merging research and industry in developing Arab countries. HBRC J 14(3):357-367. https://doi.org/10.1016/j.hbrcj .2017 .06 .002

Neborsky EV (2017) Reconstruction of the university model: transition to the 4.0 format. https://mir-nauki.com/PDF/26PDMN417.pdf. Accessed 28 Feb 2019

Patthirasinsiri N, Wiboonrat M (2017) Measuring intellectual capital of science park performance for newly established science parks in Thailand. Kasetsart J Soc Sci. https://doi.org/10.1016/j. kjss.2017.10.001

Şimşek K, Yıldırım N (2016) Constraints to open innovation in science and technology parks. Proc Soc Behav Sci 235:719-728. https:// doi.org/10.1016/j.sbspro.2016.11.073

Skobelev PO, Borovik SY (2017) On the way from industry 4.0 to industry 5.0: from digital manufacturing to digital society. Soc Ind 2(6):307-311

Statistical Yearbook of the Republic of Belarus (2018). http://www. belstat.gov.by/en/ofitsialnaya-statistika/publications/statistica 1-publications-data-books-bulletins/public_compilation/index _12543/. Accessed 30 Jan 2019

Steruska J, Simkova N, Pitner T (2019) Do science and technology parks improve technology transfer? Technol Soc. https://doi. org/10.1016/j.techsoc.2019.04.003

The most digital countries in the world (2017). https://hbr-russia.ru/ innovatsii/trendy/p23271. Accessed 30 Jan 2019

Vásquez-Urriago AR, Barge-Gil A, Modrego Rico A (2016) Science and technology parks and cooperation for innovation: empirical evidence from Spain. Res Policy 45(1):137-147. https://doi. org/10.1016/j.respol.2015.07.006

Yasheva GA (2008) Cluster concept of innovative development of the economy: the rationale and mechanism for implementation. RUDN J Econ 4:63-67 